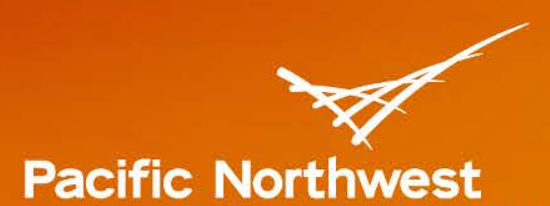

\title{
Predictive Engineering Tools for Injection- Molded Long-Carbon-Thermoplastic Composites: Weight and Cost Analyses
}

August 2016

Ba Nghiep Nguyen, Leonard S. Fifield

Pacific Northwest National Laboratory, Richland, WA 99354

Umesh N. Gandhi

Toyota Research Institute North America, Ann Arbor, MI 48105

Steven Mori

Magna Exteriors and Interiors Corporation, Aurora, Ontario, Canada

Eric J. Wollan

PlastiComp, Inc., Winona, MN 55987

Project period: From October $1^{\text {st }} 2012$ to September $30^{\text {th }}, 2016$

Reporting period end date: March $31^{\text {st }}, 2016$

Quarterly report submitted to:

Aaron Yocum, National Energy Technology Laboratory, Morgantown, WV 26507 
PNNL-25646

DISCLAIMER

This report was prepared as an account of work sponsored by an agency of the United States Government. Neither the United States Government nor any agency thereof, nor Battelle Memorial Institute, nor any of their enmployees, makes any warranty, express or implied, or assumes any legal liability or responsibility for the accuracy, completeness, or usefulness of any information, apparatus, product, or process disclosed, or represents that its use would not infringe privately owned rights. Reference herein to any specific conmercial product, process, or service by trade name, trademark, mannfacturer, or otherwise does not necessarily constitute or imply its endorsement, recommendation, or favoring by the United States Government or any agency thereof, or Battelle Memorial Institute. The views and opinions of authors expressed herein do not necessarily state or reflect those of the United States Government or any agency thereof.

PACIFIC NORTHWEST NATIONAL LABORATORY

operated by

BATTELL.

for the

UNITED STATES DEPARTMENT OF ENERGY

wnder Contract $D E-A C 05-76 R L 01830$

Priated in the United States of America

Available to DOF amd DOF contractors from the Office of Scientific and Technicsl Information.

P.O. Bor 62, Oal Kidge, TN 37831-0062;

$\mathrm{ph}$ (865) $576-8401$

email: reports_adonis.ostigow

Avrilable to the public from the National Technical Informatioe Service, U.S. Department of Commerce, 5285 Port Koyal Kd, Sprimgield, VA 2216 ph: (800) $553-6847$ far (703) 605-690 email: orders@ntis fedworld.gov

online ordering: bttp://wwn ntis.goviordering htm

th

This document was printed on recycled paper.

(92003) 


\section{Predictive Engineering Tools for Injection- molded Long-Carbon-Fiber Thermoplastic Composites: Weight and Cost Analyses}

Ba Nghiep Nguyen, Leonard S. Fifield

Pacific Northwest National Laboratory, Richland, WA 99354

Umesh N. Gandhi

Toyota Research Institute North America, Ann Arbor, MI 48105

Steven Mori

MAGNA Exteriors and Interiors Corporation, Aurora, Ontario, Canada

Eric J. Wollan

PlastiComp, Inc., Winona, MN 55987

August 2016

Report submitted to:

Aaron Yocum, National Energy Technology Laboratory, Morgantown, WV 26507

Prepared for

the U.S. Department of Energy

under Contract DE-AC05-76RL01830

Pacific Northwest National Laboratory

Richland, Washington 99352 


\section{Introduction}

This project proposed to integrate, optimize and validate the fiber orientation and length distribution models previously developed and implemented in the Autodesk ${ }^{\circledR}$ Simulation Moldflow ${ }^{\circledR}$ Insight (ASMI) package for injection-molded long-carbon-fiber (LCF) thermoplastic composites into a cohesive prediction capability. The current effort focused on rendering the developed models more robust and efficient for automotive industry part design to enable weight savings and cost reduction. The project goal has been achieved by optimizing the developed models, improving and integrating their implementations in ASMI, and validating them for a complex three-dimensional (3D) LCF thermoplastic automotive part (Figure 1). Both polypropylene (PP) and polyamide-6,6 (PA66) were used as resin matrices. After validating ASMI predictions for fiber orientation and fiber length for this complex part against the corresponding measured data, in collaboration with Toyota Research Institute North America (Toyota) and Magna Exteriors and Interiors Corp. (Magna), PNNL developed a method using the predictive engineering tool to assess the stiffness performance of the LCF/PA66 complex part design. Structural three-point bending analyses of the complex part and similar parts in steel were then performed for this purpose, and the team has demonstrated the use of stiffness-based complex part design assessment to evaluate weight savings relative to the body system target $(\geq 35 \%)$ set in Table 2 of DE-FOA-0000648 (Area of Interest (AOI) \#1) [1]. Starting from the part-to-part analysis, the predictive engineering (PE) tools enabled an estimated weight reduction for the vehicle body system using $50 \mathrm{wt} \%$ LCF/PA66 parts relative to the current steel system. This analysis estimated the manufacturing costs, including materials, for making the equivalent part in steel and compared it to the costs for making the LCF/PA66 part to determine the cost per "saved" pound.

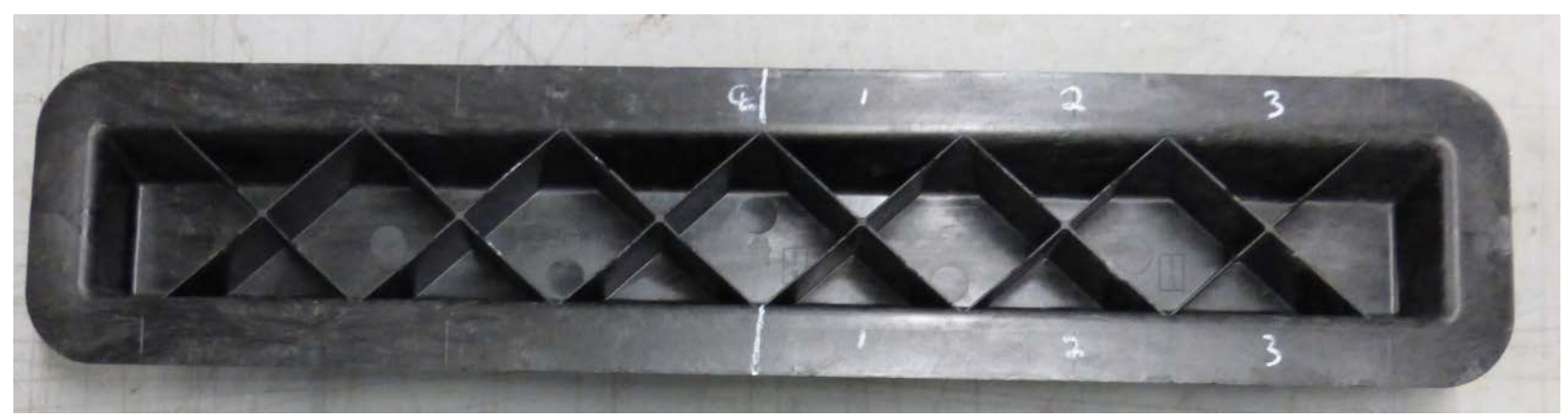

Figure 1. The 3D complex automotive ribbed part designed with the injection-molded $50 \mathrm{wt} \%$ LCF/PA66 material for a replacement of a similar part in steel without ribs.

\section{Weight Reduction Achieved with 50 wt\% LCF/PA66}

\subsection{Weight reduction achieved for a single part}

In the second fiscal year (FY) 2016 quarterly report [2], we reported a weight reduction that could be achieved by replacing a 1-mm thick non-ribbed part in steel with a 2.8-mm thick ribbed part molded from the $50 \mathrm{wt} \%$ LCF/PA66 material. The method to estimate weight reduction involves the following steps [2]:

1. Run ASMI analysis of the $30 \mathrm{wt} \% \mathrm{LCF} / \mathrm{PA} 66$ ribbed part and compare predicted fiber orientation and length results to the measured data.

2. Export ASMI nodal fiber orientation and weight-average length result data. 
3. Import data into ABAQUS ${ }^{\circledR}$ via EMTA-NLA ${ }^{1}$.

4. Perform bending elastic analysis of the $30 \mathrm{wt} \%$ LCF/PA66 part using EMTA-NLA/ABAQUS ${ }^{\circledR}$ to obtain load-deflection response.

5. Perform ABAQUS ${ }^{\circledR}$ bending elastic analysis of similar non-ribbed parts in steel with different wall thicknesses to obtain load-deflection responses.

6. Determine the wall thickness of the part in steel that produces the same load-deflection response as the $30 \mathrm{wt} \%$ LCF/PA66 part.

7. Manufacturing constraint: Parts in steel require thickness $\geq 1 \mathrm{~mm}$.

8. If the $30 \mathrm{wt} \% \mathrm{LCF} / \mathrm{PA} 66$ part does not meet the stiffness performance, increase the fiber loading to $40 \%$ or $50 \%$, and then repeat Steps 4,6 , and 8 by replacing $30 \mathrm{wt} \%$ with 40 or 50 wt\% until achieving the load-deflection response target.

9. Evaluate weight reduction achieved.

10. Estimate manufacturing cost including material cost for making the equivalent part in steel and compare to the costs for making the LCF/PA66 part to determine the cost per "saved" pound.

Table 1 summarizes the part-to-part comparison from the analysis that indicates a $43.2 \%$ weight reduction for the complex part. The 50wt\% LCF/PA66 ribbed part has a 2.8-mm wall thickness and 1.25$\mathrm{mm}$-thick ribs. The equivalent non-ribbed part in steel is 1-mm thick. The weight reduction achieved for the composite part exceeds the system target ( $\geq 35 \%$ ) set in Table 2 of DE-FOA-0000648 (AOI \#1) [1].

Table 1. Part-to-part comparison to evaluate the weight reduction achieved with $50 \mathrm{wt} \%$ LCF/PA66 [2].

$50 w t \%$ LCF/PA66 ribbed part

(2.8-mm wall thickness)

Density $\left(\mathrm{g} / \mathrm{cm}^{3}\right)$

Volume $\left(\mathrm{cm}^{3}\right)$

Weight (lb)
1.39

224.64

$0.688(43.2 \%$ reduction $)$
Feasible non-ribbed part in Steel (1-mm wall thickness)

7.85

70

1.211

\subsection{Weight reduction achieved for a body-in-white}

Knowing the weight reduction that would be achieved for a single part, Toyota conducted a study to determine the components of the body-in-white (Figure 2) that could potentially be replaced with composite material parts using the $50 \mathrm{wt} \%$ LCF/PA66. The body-in-white considered by Toyota weighs $225 \mathrm{~kg}$, and the steel components of the body-in-white selected for replacement weigh $115 \mathrm{~kg}$. With an estimated $40 \%$ weight reduction achievable with composite materials, the total new weight of the candidate components for replacement would be $69 \mathrm{~kg}$. This would reduce the weight of the body-inwhite to $179 \mathrm{~kg}$ to achieve 20\% weight reduction. Due to performance and other considerations, only certain body system components could be replaced with parts produced using injection molded materials. Practical considerations based on manufacturing insights were included in the weight reduction estimates.

If closures are included in addition to the body-in-white in the weight reduction analysis, Toyota found that a $22.5 \%$ weight reduction may be achieved. The current weight reduction estimate is based on weight savings in body-in-white, closures and bumpers. Typically, a lighter weight body-in-white could also result in lighter secondary components (i.e., engine, brakes, suspension, etc.), which would lead to

\footnotetext{
${ }^{1}$ EMTA-NLA = Eshelby-Mori-Tanaka Approach to Non-Linear Analysis ABAQUS ${ }^{\circledR}$ user subroutine
} 
further vehicle weight savings. In this work, the components whose main contribution is stiffness (bending) related were considered for replacement to achieve weight reduction. The components that play a significant role in the impact performance were not considered in the scope of this project.

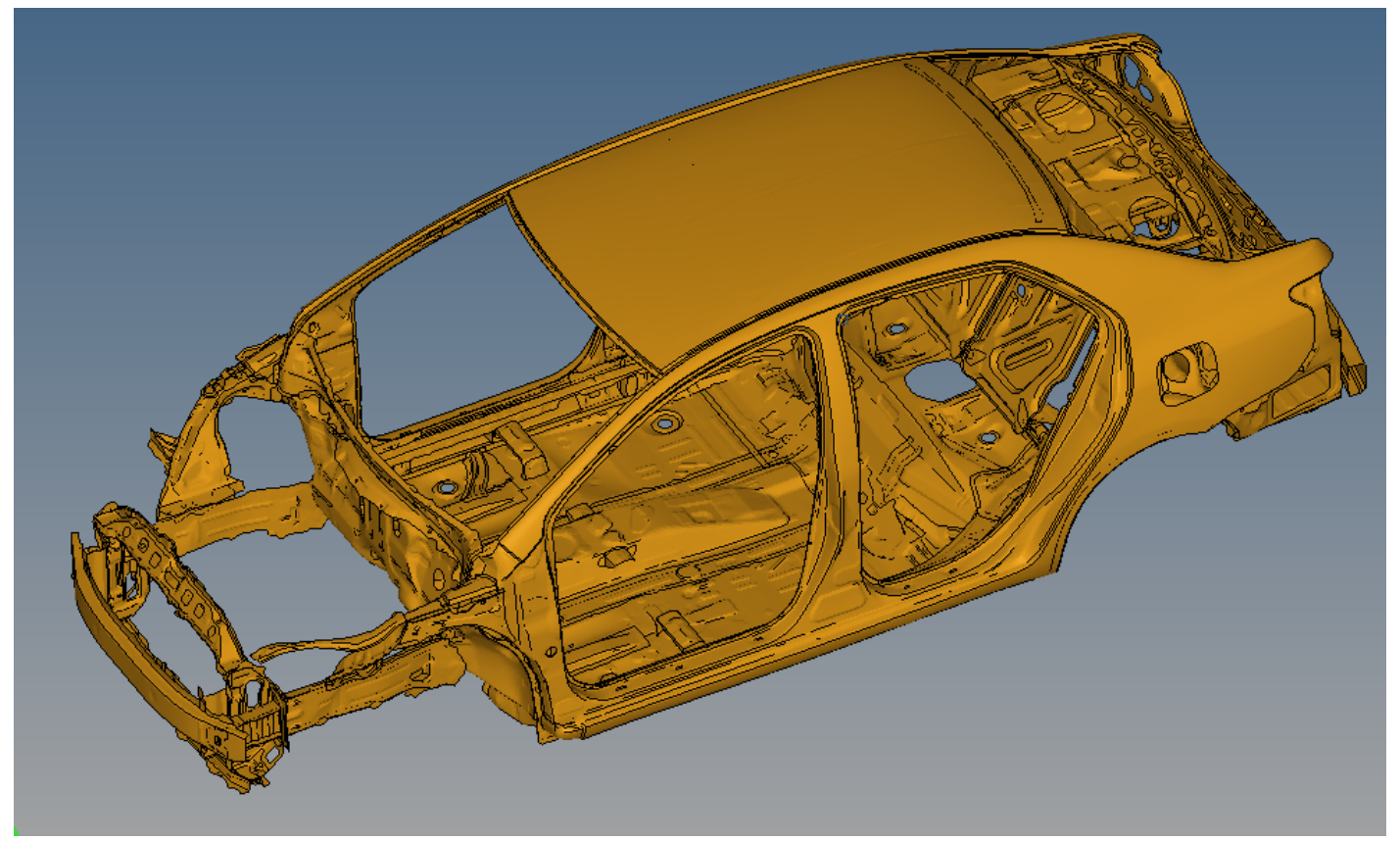

Figure 2. It is estimated that a $20 \%$ weight reduction is achievable for a body in white using the injection molded LCF/PA66 material.

\section{Cost Per Saved-Pound Estimates}

\subsection{Cost of saving 1 pound based on the actual cost of carbon fibers}

In discussion with PlastiComp, Inc. (PlastiComp), Magna calculated the estimated cost to make the $50 \mathrm{wt} \%$ LCF/PA66 ribbed part based on the annual production rate of 100,000 parts per year. The cost to make a non-ribbed complex part in steel based on the same production rate was obtained from Toyota. Cost comparison indicates that the cost to make the composite part would be 3.2 times that of the part in steel. As a result, the cost to save 1 pound would be approximatively 5 times the target in Table 2 of DEFOA-0000648 (AOI \#1) [1].

\subsection{Cost of saving 1 pound based on $\$ 5$ per pound of carbon fibers}

PlastiComp estimated that $42 \%$ cost reduction for $50 \mathrm{wt} \%$ LCF/PA66 compounds could be achieved if carbon fibers were available at $\$ 5$ per pound. The cost to make $50 \mathrm{wt} \%$ LCF/PA66 compounds (pellets) includes the material cost (for carbon fibers and the PA66 resin) and the compounding cost. Given that the cost of carbon fibers is much higher than that of PA66, the material cost is dominated by the carbon fiber cost. From Magna information regarding the standard cost to make this composite complex part and accounting for the reduced cost for compounds discussed above, molding a $50 \mathrm{wt} \%$ LCF/PA66 complex part weighing $0.688 \mathrm{lb}$ would incur a cost approximately 30\% lower than the current cost estimates. This would lead to the following conclusions for $\$ 5$ per pound carbon fiber:

- The cost to make the composite part would be more than twice the cost for the part in steel,

- $\quad$ The cost per saved pound would be about 2.5 times the target. 
Table 2 summarizes the analyses considering the current and \$5/lb costs of carbon fibers and Table 3 gives an overview of the cost and weight reduction impacts on replacing steel parts with composite parts.

Table 2. Estimates for the cost of saving 1 pound.

\begin{tabular}{|c|c|c|c|}
\hline & $50 w t \%$ CFPA66 part & $\begin{array}{c}50 w t \% \text { CFPA66 part } \\
\text { (at } \$ 5.00 / / \mathrm{b} \text { ) }\end{array}$ & $\begin{array}{c}\text { Feasible Part in Steel } \\
\text { (1-mm Thick) }\end{array}$ \\
\hline Weight (Ib) & 0.688 & 0.688 & $1.211(43.2 \%)$ \\
\hline Cost & $\begin{array}{l}3.2 \text { times the cost of the part } \\
\text { in steel }\end{array}$ & $\begin{array}{l}2.1 \text { times the cost of the } \\
\text { part in steel }\end{array}$ & --- \\
\hline $\begin{array}{l}\text { Cost per saved } \\
\text { pound }\end{array}$ & $\sim 5$ times the target & $\sim 2.5$ times the target & --- \\
\hline
\end{tabular}

Table 3. Cost and weight reduction impacts on replacing steel parts with composite parts.

\begin{tabular}{|c|c|c|c|c|}
\hline Vehicle system & System definition & Weigh reduction & Cost per lb saved & $\begin{array}{c}\text { Additional } \\
\text { requirements }\end{array}$ \\
\hline Targets & $\begin{array}{c}\text { Body in white, } \\
\text { closures, fenders, } \\
\text { bumpers }\end{array}$ & $\geq 35 \%$ & $<\$ 3.18 / \mathrm{lb}$ & $\begin{array}{c}\text { Safety }=\text { OK } \\
\text { Structure }=\text { OK }\end{array}$ \\
\hline Results & $\begin{array}{c}\text { Body in white } \\
\text { Closures }\end{array}$ & $22.5 \%$ & $\sim 5$ times Target & $\begin{array}{c}\text { Safety }=\text { NA } \\
\text { Structure }=\text { OK }\end{array}$ \\
\hline $\begin{array}{c}\text { (if } \$ 5 / \mathrm{lb} \text { carbon } \\
\text { fibers) }\end{array}$ & $\begin{array}{c}\text { Body in white } \\
\text { Closures }\end{array}$ & Same & 2.5 times Target & Same \\
\hline
\end{tabular}

\section{References}

[1] U. S. Department of Energy, National Energy Technology Laboratory, Funding Opportunity Number: DE-FOA-0000648. "Predictive Modeling for Automotive Lightweighting Applications and Advanced Alloy Development for Automotive and Heavy-Duty Engines”. Announcement Type: 003. CFDA Number: 81.086 Conservation Research and Development, Issue Date: 05/04/2012.

[2] Nguyen BN, Fifield LS, Wang J, Franco C, Lambert L, Baird DG, Gandhi UN, Mori S, Tucker III CL, Wollan EJ (2016). Predictive Engineering Tools for Injection-Molded Long-Carbon-Fiber Thermoplastic Composites - FY 2016 Second Quarterly Report; PNNL-25372; Pacific Northwest National Laboratory, Richland, WA. 


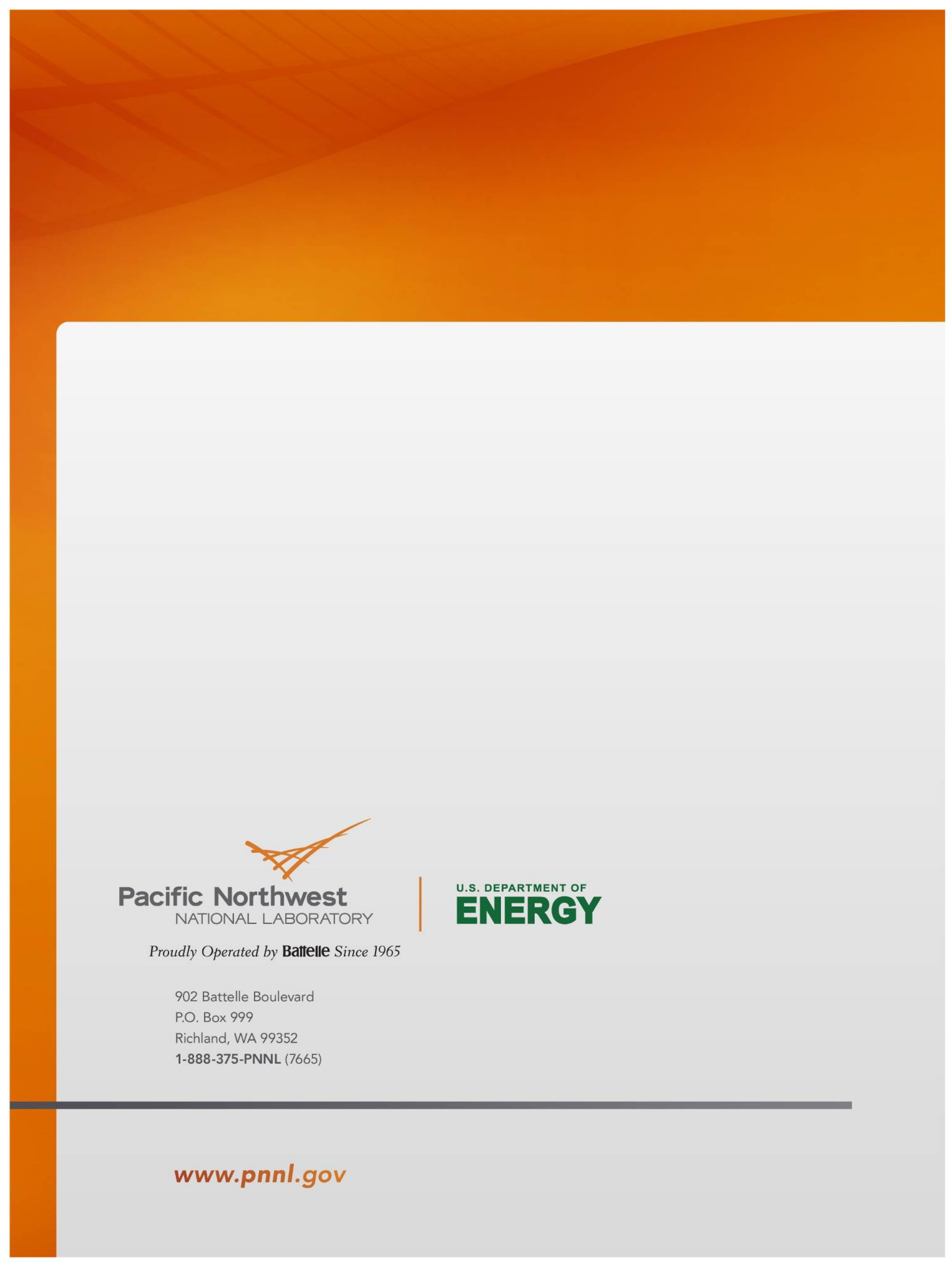

